African Crop Science Journal by African Crop Science Society is licensed under a Creative Commons Attribution 3.0 Uganda License. Based on a work at www.ajol.info/ and www.bioline.org.br/cs DOI: http://dx.doi.org/10.4314/acsj.v25i3.3

\title{
COMPOSITION AND VARIATION OF FATTY ACIDS AMONG GROUNDNUT CULTIVARS IN UGANDA
}

\author{
E. ACHOLA ${ }^{1}$, P. TUKAMUHABWA ${ }^{1}$, J.ADRIKO ${ }^{2}$, R. EDEMA ${ }^{1}$, S.E. MWALE ${ }^{1,6}$, P. GIBSON ${ }^{1}$, \\ P. NAVEEN ${ }^{3}$, V. OKUL ${ }^{1}$, D. MICHAEL ${ }^{4}$ and D.K. OKELLO ${ }^{5}$ \\ ${ }^{1}$ Department of Agricultural Production, School of Agricultural Sciences, Makerere University, \\ P. O. Box 7062, Kampala, Uganda \\ ${ }^{2}$ Biodiversity and Biotechnology Programme, National Agricultural Research Laboratories, Kawanda, \\ P. O. Box 7065 Kampala, Uganda
}

${ }^{3}$ New Mexico State University, Agricultural Science Center. Clovis, 2346 SR 88 Clovis, New Mexico, USA

${ }^{4}$ Department of Pathology, The University of Georgia, Miller Plant Sciences Building, Athens GA, 30602, USA

${ }^{5}$ National Semi-Arid Resources Research Institute, P. O. Box 56 Soroti, Uganda

${ }^{6}$ Department of Biological Sciences, Mzuzu University, Private Bag 201, Mzuzu, Malawi

Corresponding author: esterjocelyn@gmail.com

(Received 27 September, 2016; accepted 31 July, 2017)

\begin{abstract}
Groundnuts (Arachis hypogaea L.) contain approximately $44-56 \%$ oil made up of fatty acids. Oleic and linoleic acids comprise about $80 \%$ of fatty acids in groundnuts. Groundnuts with $>80 \%$ oleic are beneficial health-wise and also improve groundnut quality, flavour, and extended shelf-life, which is beneficial to traders. In Uganda, however, little is known about the fatty acids content of commercially available cultivars. This study was undertaken to determine the fatty acid composition of the most recently released commercially available groundnut cultivars in Uganda. Eleven groundnut genotypes were profiled for different fatty acids using gas chromatography (GC). Data were recorded in percentages from chromatographs and totaled up to about $100 \%$. Oleic to linoleic ratios $(\mathrm{O} / \mathrm{L})$ and iodine values were calculated from fatty acid data. Groundnut genotypes tested differed significantly $(\mathrm{P}<0.05)$ in oleic, linoleic, palmitic, behenic, gadoleic, arachidic and palmitoleic acids. Oleic acid was highest in Lot 197 line, and linoleic acid was lowest in the same line. Oleic acid was lowest in Serenut 7 (43.19\%) and linoleic acid was highest in the same line (33.45\%). The lowest iodine value was observed in 197 (84.14); and the highest in Serenut 9T (96.59). Significant correlations $(\mathrm{P}<0.001)$ were observed between most of the fatty acids, except between arachidic versus gadoleic, stearic and gamma linoleic.
\end{abstract}

Key Words: Arachis hypogaea, gas chromatography, linoleic, oleic

\section{RÉSUMÉ}

L'Arachide (Arachis hypogaea L.) contient approximativement 44-55\% d'huile faites d'acides gras. Les acides oléique et linoléique constituent environ $80 \%$ des acides gras dans l'arachide. Les arachides avec plus de $80 \%$ d'oléiques sont bénéfiques pour la santé et aussi améliorent la qualité de l'arachide, le goût, et une longue durée de conservation, avantageux pour les commerçants. En Ouganda, toutefois, très peu d'informations sont disponibles concernant la teneur en acides gras des cultivars commercialement disponibles. Cette étude a été entreprise pour déterminer la composition en acide gras de la majorité des cultivars d'arachides récemment libérés et commercialement disponibles en Ouganda. Onze génotypes d'arachide ont été profilés pour les différents acides gras en utilisant le gaz chromatographie (GC). Les données ont été collectées des chromatographes en pourcentages et additionnées 
jusqu'à environ 100\%. Les rapports d'oléiques au linoléiques $(\mathrm{O} / \mathrm{L})$ et les valeurs d'iode ont été calculées à partir des données des acides gras. Les génotypes d'arachide testés ont été significativement $(\mathrm{P}<0,05)$ différents en acides oléique, linoléique, palmitique, béhénique, gadoléique, arachidique et palmitoleique. L'acide oléique était le plus élevé dans la lignée Lot 197, et l'acide linoléique était le plus faible dans la même lignée. L'acide oléique était le plus faible en Serenut 7 (43,19\%) et l'acide linoléique était le plus élevé dans la même lignée (33,45\%). La plus faible valeur de l'iode était observée dans $197(84,14)$; et la valeur la plus élevée dans Serenut 9T $(96,59)$. Des corrélations significatives $(\mathrm{P}<0,001)$ étaient observée entre la majorité des acides gras, sauf entre l'acide arachidique contre les acides gadoléique, stéarique et gamma linoléique.

Mots Clés: Arachis hypogaea, gaz chromatographie, linoléique, oléique

\section{INTRODUCTION}

Groundnut (Arachis hypogaea $\mathrm{L} ., 2 \mathrm{n}=4 \mathrm{x}=40$ ) is an important oilseed and cash crop for farmers of the arid and semi-arid tropics. In Uganda, groundnut is a significant source of cash income and contributes significantly to food security (Okello et al., 2013). Oleic, linoleic, and palmitic fatty acids constitute $\sim 90 \%$ of the total fatty acids (Barkley et al., 2013).

Oleic and linoleic fatty acid composition of groundnuts play an important role in determining how beneficial groundnuts are for humans. For instance, many studies have reported that groundnuts with high oleic to linoleic ratio $(>2)$ are more beneficial to human beings compared to 'normal' oleic groundnuts with a ratio of $<2$. This is because a high oleic to linoleic ratio confers health benefits (Garcia et al., 2006) and good seed oxidative stability, thus extended shelf life (Janila et al., 2013). In addition, groundnut oil is considered one of the healthy cooking oils; since the ratio of unsaturated to saturated fatty acids is very high (Johnson and Saikia, 2009).

Fatty acids, both free and as part of complex lipids, play a number of key roles in metabolism, as major metabolic fuel (storage and transport of energy), as well as essential components of all membranes and gene regulators (Rustan and Drevon, 2005). Saturated fatty acids are 'filled' (saturated) with hydrogen and straight hydrocarbon chains, with an even number of carbon atoms; while unsaturated fatty acids generally contain double bonds in their structure (Rustan and
Drevon, 2005). Saturated fatty acids are stable and have been associated with heart problems. Saturated fat also increases high-density lipoprotein (HDL) cholesterol, the total cholesterol (TC) to HDL cholesterol ratio, a risk marker for Cardio Vascular Disease (CVD) (Barbour et al., 2015).

Oleic acid, a monounsaturated fatty acid (MUFA) is, however, thought to reverse the above effects. Oleic acid (C18:1) has been associated with several human health benefits, including; decreased risk of cardiovascular disease (CVD), by reducing the levels of serum low-density lipoproteins (LDL) cholesterol; and maintaining the levels of highdensity lipoproteins (HDL), without causing significant weight gain (Barbour et al., 2015). MUFAs decrease plasma triglyceride levels in comparison with carbohydrates (KrisEtherton, 1999). In addition, the MUFAs help in hindering the development of adrenoleukodystrophy (ALD) (Rizzo et al., 1986) and reversing inhibitory effects of insulin production (Vassiliou et al., 2009). MUFAs may also decrease platelet aggregation and increase ûbrinolysis, thereby protecting against thrombogenesis (Kris-Etherton, 1999). It also has anti-inflammatory properties that activate different pathways of immune competent cells (Carrillo et al., 2012).

Polyunsaturated fatty acids (PUFAs) such as linoleic (C18:2), are recognised for their susceptibility to oxidative rancidity, such that when heated at high temperatures makes it dangerous for human consumption (Isleib e $t$ al., 2006). This instability leads to formation of trans-fatty acid, which has detrimental 
effect on human health as it causes cardiovascular disease (CVD) (Wang et al., 2015). In addition, linoleic acid is a metabolic precursor to arachidonic acid and eicosanoids, which have been associated with an increased risk of inflammation, cancers, CVD and neurological disorders (Whelan, 2008). Iodine value is directly proportional to the degree of unsaturation (number of double bonds). An increase in iodine value, therefore, indicates high susceptibility of lipid to oxidative rancidity due to high degree of unsaturation (Gupta, 2011).

Following the benefits conferred by major fatty acids in groundnuts, it is important to know the exact quantities of fatty acids present per genotype so that the genetic potential of genotypes can be exploited by breeders. This study was, therefore, carried out to profile fatty acids, especially oleic, in the commercially available Ugandan cultivars.

\section{MATERIALS AND METHODS}

Eleven groundnut cultivars (Table 1) were used for this study. Ten of these were obtained from the National Groundnut Improvement Department at National Semi-Arid Resources Research Institute (NaSARRI), Serere in Uganda. Lot 197, a high oleic line, was acquired from New Mexico State University (NMSU) Peanut Improvement Program, USA. Varieties obtained from NaSARRI were commercially available varieties and the most recently released by National Agricultural Research Organization (NARO) in Uganda.

Eleven groundnut samples were stored at room temperature at NaSARRI. Each of the samples were collected in two $250 \mathrm{~g}$ replicates. Fatty acid extraction procedures were carried out according to the Association of Official Agriculture Chemists (AOAC International) $19^{\text {th }}$ Edition. Briefly, each of the groundnut variety sample $(250 \mathrm{~g})$ were thoroughly ground to a fine paste, using IKA WERKE M20 water-cooled grinding machine to obtain a homogenous mixture. Fifty microlitres $(50 \mu \mathrm{l})$ of the different groundnut samples of each genotype, was extracted in 1:1 n-methyl- formamide: Fioxane solution, and dried under nitrogen. $50 \mu \mathrm{l}$ of $0.5 \%$ (w/ v/) butylated hydroxytoluene was added to prevent oxidation.

Samples were then dried under nitrogen and saponified with 5\% methanolic-potassium hydroxide, followed by transmethylation with $14 \%$ methanolic-boron trifluoride, to form fatty acid methyl esters (FAMEs) (Shipley et al., 1993). Water was removed by putting samples through anhydrous magnesium sulphate. Minicolumns and FAMEs were purified on salicylic acid mini-columns. Each sample was reconstituted in $500 \mu \mathrm{l}$ chloroform for gas chromatography analysis.

Reconstituted FAMEs were analysed by gas chromatography (GC) on a HP5890 Series II Gas Chromatograph with HP7673 Autosampler. The above were then introduced onto a DB-225 column $(30 \mathrm{~m} \times 0.25 \mathrm{~mm}$ with 0.15 $\mu \mathrm{m}$ film thickness) (JandW Scientific), using a split injector set at $250{ }^{\circ} \mathrm{C}$ with a $1: 25$ split ratio. The carrier gas used was ultrapure helium at $1 \mathrm{ml} \mathrm{min}^{-1}$. The $\mathrm{GC}$ procedure was carried out at $100{ }^{\circ} \mathrm{C}$ for 2 minutes, $25^{\circ} \mathrm{C}$ minutes ${ }^{-1}$ to $180^{\circ} \mathrm{C}, 15^{\circ} \mathrm{C}$ minutes ${ }^{-1}$ to $200^{\circ} \mathrm{C}$, $4{ }^{\circ} \mathrm{C}$ minutes ${ }^{-1}$ to $225{ }^{\circ} \mathrm{C}$ held at 6 minutes. A flame ionisation detector was set at $300{ }^{\circ} \mathrm{C}$, and peak areas were recorded using HPChemstation software. FAME peaks were identified by using retention times compared to standard fatty acid methyl esters (FAMEs, $\mathrm{Nu}$ Check Prep, Inc., Elysian MN).

Data analysis. Analysis of variance and mean comparison of fatty acids composition of the 11 genotypes, was done in GenStat $12^{\text {th }}$ Edition, following a completely randomised design. Means were separated using Fisher's protected Least Significant Difference (LSD) scores at 0.05 probability level. Pearson correlations between the different fatty acids among genotypes were also generated. The Linear Mathematical Model used was:

$$
Y_{i j}=\mu+T i+{ }^{e i j}
$$


TABLE 1. Groundnut varieties used in the fatty acids study at Chemiphar Laboratories, Kampala, Uganda

\begin{tabular}{|c|c|c|c|c|c|}
\hline $\begin{array}{l}\text { Common } \\
\text { name }\end{array}$ & Variety name & Pedigree & $\begin{array}{l}\text { Year of } \\
\text { release }\end{array}$ & Oleic level & Other attributes \\
\hline Serenut 5R & ICGV-SM 93535 & ICGM 522 X RG 1 & 2010 & Unknown & $\begin{array}{l}\text { Confectionary and Butter type, attractive red market color, Leafspot } \\
\text { resistant }\end{array}$ \\
\hline Serenut 6T & ICGV-SM 99566 & ICGV 93437 X ICGV-SM 93561 & 2010 & Unknown & Butter, Confectionary type, early maturing (90 days) \\
\hline Serenut 7T & SGV 99018 & CG 7 X ICGV 90704 & 2011 & Unknown & Confectionary type, good for condiments, flour \\
\hline Serenut 8R & SGV 99019 & CG 7 X ICGV 90704 & 2011 & Unknown & $\begin{array}{l}\text { Drought and Leafspot resistant, good for butter, attractive red market } \\
\text { colour }\end{array}$ \\
\hline Serenut 9T & SGV 99024 & CG 7 X ICGV 90704 & 2011 & Unknown & Leafspot resistant, very sweet, Confectionary type \\
\hline Serenut $10 \mathrm{R}$ & SGV 99044 & CG 7 X ICGV 90704 & 2011 & Unknown & Leafspot and leaf miner resistant \\
\hline Serenut $11 \mathrm{~T}$ & SGV 99031 & CG 7 X ICGV 90704 & 2011 & Unknown & Leafspot tolerant, Confectionary type , ease of shelling \\
\hline Serenut $12 \mathrm{R}$ & SGV 99048 & CG 7 X ICGV 90704 & 2011 & Unknown & Leafspot tolerant, Confectionary type, attractive red market color \\
\hline Serenut $13 \mathrm{~T}$ & SGV 99052 & CG 7 X ICGV 90704 & 2011 & Unknown & Leafspot tolerant, Confectionary type , ease of shelling \\
\hline Serenut $14 \mathrm{R}$ & SGV 99064 & CG 7 X ICGV 90704 & 2011 & Unknown & Leafspot resistant, confectionary type, ease of harvesting \\
\hline Lot 197 & - & NM02322 x NuMex-01 & $\begin{array}{l}\text { Advanced } \\
\text { cross }\end{array}$ & High oleic & Early maturing \\
\hline
\end{tabular}

197 are known to be rosette resistant, high yielding and drought tolerant, in addition to the listed attributes 
$\mathrm{Y}_{\mathrm{ij}}$ is the $\mathrm{jth}$ observation of the ith treatment

$\mu$ is the population mean, ${ }_{\mathrm{Ti}}$ is the treatment effect of the ith treatment, eij $=$ the experimental error

Oleic to linoleic ratio $(\mathrm{O} / \mathrm{L})$ was calculated from:

$$
\frac{\% \text { fatty acid of oleic }}{\% \text { fatty acid of linoleic }}
$$

Iodine value was calculated from:

$(0.8601 \times \%$ oleic acid $)+(1.7321 \times \%$ linoleic acid $)+(0.7854 \times \%$ Eicosapentaenic acid $)$ (Mozingo et al., 1988).

\section{RESULTS}

Nine fatty acids were consistently present in groundnut samples. Oleic and linoleic acids accounted for $>80 \%$ of the fatty acids; while oleic, linoleic, palmitic and stearic acids collectively accounted for $\sim 95 \%$ (Table 2 ). The rest, $(<5 \%)$ constituted behenic, palmitoleic, arachidic, gadoleic and gamma linoleic fatty acids. Significant differences $(\mathrm{P}<0.001)$ were observed among oleic, linoleic, behenic and palmitoleic fatty acids. Palmitic and gadoleic fatty acids were significant at $\mathrm{P}<0.05$.

A moderate oleic acid composition $(52.79 \%)$ and a low linoleic acid mean (26.79\%) were observed in Serenut 8R (Table $2)$. Serenut $6 \mathrm{~T}$ and S.7T had the highest palmitic acid means (18.63 and $18.17 \%$, respectively). All the means for arachidic, behenic, palmitoleic, gadoleic and gamma linolenic acids ranged between $0.37-0.78 \%$; and palmitoleic acid between 0.06 and $0.17 \%$. Serenut 5R had the least of both behenic and palmitoleic acids (Table 2). Oleic acid mean was highest in Lot 197 line, which also had the lowest linoleic acid. Serenut 7 had the lowest oleic acid (43.19\%) and highest linoleic acid mean $(33.44 \%)$.

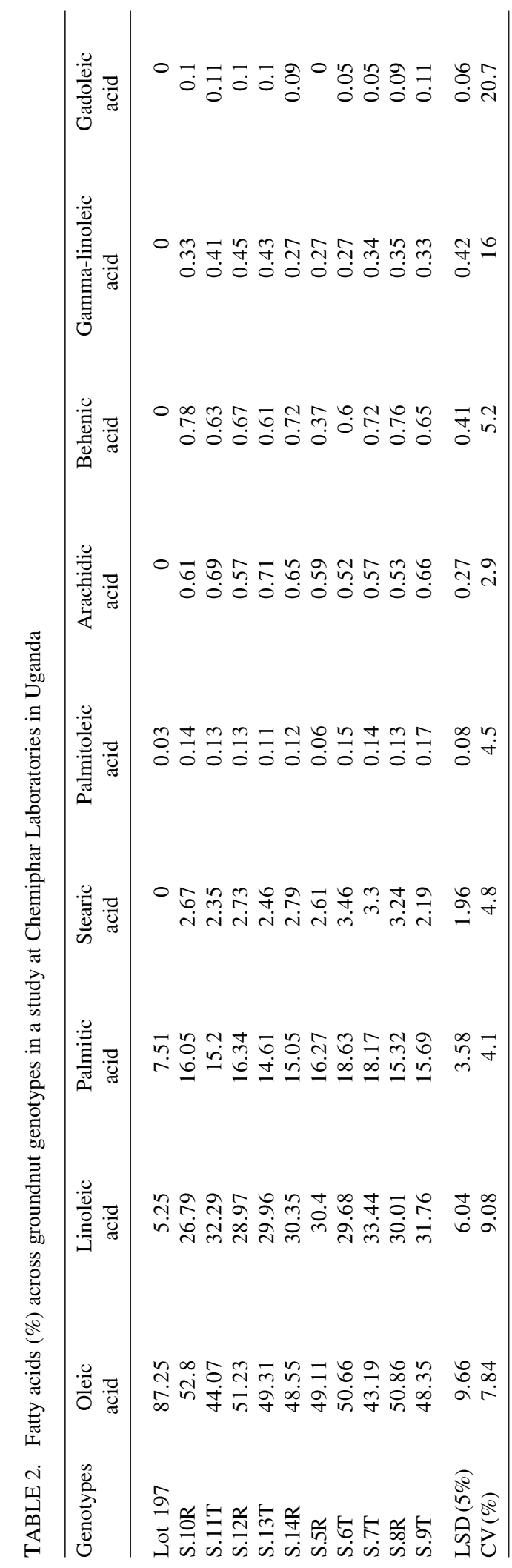


Stearic, arachidic, behenic, gamma-linoleic and gadoleic acids were absent in Lot 197. The O/L increased as the amount of oleic acid increased, thus the highest ratio being in Lot 197 (16.6) and the lowest in Serenut 7T (1.30) (Table 3). However, Serenut 8R registered the highest $\mathrm{O} / \mathrm{L}$ among the local cultivars. The lowest iodine value was observed in 197 (84.14) and the highest in Serenut 9T (96.59) (Table 3).

Significant correlations $(\mathrm{P}<0.001)$ based on genotype means were observed between most of the fatty acids, except between arachidic versus gadoleic, stearic and gamma linoleic (Table 4). The highest correlation was observed between oleic and linoleic acids $(\mathrm{r}=$ 0.99 ); at $\mathrm{P}<0.001$; followed by oleic and palmitic acids $(r=0.96)$. The relationship in the two cases were, however, negative (Table 4). The lowest, but positive correlation $(\mathrm{r}=$ 0.5 ) was observed between palmitoleic acid, and arachidic acids and between gadoleic and stearic acids (Table 4).

A highly significant $(\mathrm{P}<0.001)$ relationship was observed between oleic and linoleic fatty acids and iodine value (Table 5). Positive correlations were observed between linoleic, palmitic and stearic fatty acids and iodine value,

TABLE 3. Means of oleic to linoleic ratio $(\mathrm{O} / \mathrm{L})$ and Iodine values

\begin{tabular}{lrc}
\hline Variety & O/L & Iodine value \\
\hline Lot 197 & 16.6 & 84.14 \\
S.8R & 1.9 & 91.82 \\
S.6T & 1.4 & 93.84 \\
S.14R & 1.8 & 94.24 \\
S.10R & 1.7 & 94.31 \\
S.12R & 1.6 & 94.32 \\
S.5R & 1.6 & 94.90 \\
S.11T & 1.7 & 94.98 \\
S.7T & 1.3 & 95.08 \\
S.13T & 1.7 & 95.73 \\
S.9T & 1.5 & 96.59 \\
LSD $(5 \%)$ & 0.6 & 5.75 \\
CV $(\%)$ & 8.36 & 2.6 \\
\hline
\end{tabular}


TABLE 5. Correlations between major fatty acids and iodine value for groundnut

\begin{tabular}{lc}
\hline & Iodine \\
\hline Linoleic & $0.9186^{* * *}$ \\
Oleic & $-0.9178^{* * *}$ \\
Palmitic & $0.8149^{* *}$ \\
Stearic acid & $0.7129^{*}$ \\
\hline
\end{tabular}

while a negative correlation $(\mathrm{r}=-0.9178)$ was observed between oleic acid and iodine value.

\section{DISCUSSION}

The overall number of fatty acids recorded in this study was nine (Table 2). The total number of fatty acids per genotype, however, varied slightly in Lot 197; which had oleic content of $87.25 \%$ and no stearic, arachidic, behenic, gamma-linoleic and gadoleic acids. Thus, the total number of fatty acids recorded in Lot 197 was four compared to nine consistently recorderd among the Serenut 5-14 series(Table 2). This suggests that oleic acid content has an effect on the amounts; thus number of minor fatty acids since this was only observed in Lot 197 where high oleic was highest. Nonetheless, the major fatty acids consistently observed in this study were oleic, linoleic and palmitic fatty acids constituting $~ 90 \%$ of the fatty acids, irrespective of the genotype. This finding was also reported by Singhkam et al. (2012); Hassan and Ahmed (2012); Janila et al. (2015) and Wang et al. (2015), irrespective of the method of fatty acid profiling /analysis. The significant variation in both major (oleic, linoleic and palmitic acids) and minor (arachidic, behenic, palmitoleic and gadoleic) fatty acids composition among the groundnut genotypes in this study indicates genetic differences among the genotypes for the different fatty acids (Hassan and Ahmed, 2012) which is crucial for fatty acid improvement. Variation and number of fatty acids (especially minor fatty acids) among genotypes may not only be attributed to the genetic make-up of a particular cultivar, but also, conditioned by place of origin of the genotype and the environmental conditions (such as soil type) prevailing during the crop life cycle (Hassan and Ahmed, 2012).

The significant negative correlation observed between oleic versus linoleic, oleic versus palmitic acid, oleic versus stearic acid, linoleic versus palmitic acid and linoleic versus stearic (Table 4) reveal clear antagonistic relationships between the fatty acids. The very high correlation coefficients observed between oleic and linoleic acids, palmitic acids suggest close linkage of genes controlling these fatty acids. It would, therefore, be beneficial for breeders to select for these fatty acids simultaneously, rather than independently. The relationships between oleic and linoleic, palmitic fatty acids also suggests that ahFAD2 genotype may have influenced the levels of oleic, linoleic and palmitic acids (Barkley et al., 2013).

Generally, an increase in oleic acid, a monounsatuated fatty acid, was inversly proportional to linoleic acid a polyunsaturated acid, stearic and palmitic acids (Table 4), which are the major saturated fatty acids in groundnuts; similar to what was observed by Wang et al. (2015). Having identified the benefits of oleic versus the negative effects of linoleic, stearic and palmitic acids, this inverse relationship can be exploited to increase oleic acid with reduction in linoleic stearic and palmitic acids. The negative relationship between oleic and palmitic, stearic acids among the genotypes implies high chances of lowering health hazards by breeding for high oleic acid as the stearic and palmitic acid content is reduced. This is because saturated fatty acids such as palmitic and stearic acids are known to elevate plasma cholesterol and LDL concentrations by down-regulating the hepatic receptor for LDL (Connor, 1999). Increase in the oleic content will, therefore, lead to the reduction in the levels of the major saturated (palmitic and stearic acids) and polyunsaturated (linoleic acid) which should be the focus of breeding programmes. 
All the Ugandan genotypes had low oleic acid content $(<60 \%)$ and a high linoleic content $(>25 \%)$, thus a low O/L $(<2)$; while Lot 197 the line from USA had a high oleic content $(87.25 \%)$ and a very low linoleic content $(<5.25 \%)$ and a high O/L (16.6), therefore, qualifying it to be a 'high oleic' genotype (Singkham et al., 2012) and the Ugandan cultivars; normal oleic. Lot 197 also had the lowest iodine value (oleic acid was directly proportional to $\mathrm{O} / \mathrm{L}$ and inversely proportional to iodine value). The positive relationships between linoleic, stearic and palmitic fatty acids and iodine value evidently suggest that the rate of saturation of fatty acids has an effect on the iodine value which in turn increase the rancidity of oil. This finding is consisted with that of Gupta (2011), who reported that high oleic content lowers iodine value, which in turn increases oil stability. Oleic to linoleic ratio and iodine value, together are important factors in determining oil stability and shelf life, by reducing rancidity thus longer periods of storage (longer shelf life). The high oleic line Lot 197 can, therefore, be used as a donor parent to improve Ugandan cultivars for their oleic acid content during hybridisation.

The relatively high amount of oleic acid in Lot 197 line, compared to the Ugandan commercial genotypes, is attributed to the presence of a mutant allele that reverses the activity of the enzyme, ahFAD2 that converts linoleic acid to oleic acid therefore resulting in a dysfunctional ahFAD2 at both the A and B loci (Chu et al., 2009). The activity of the mutant allele is also responsible for the reduction of linoleic acid since the relationship between the fatty acids (oleic and linoleic) is strong and inversely proportional.

\section{CONCLUSION}

All the Ugandan groundnut cultivars in this study had low to moderate oleic levels and higher linoleic, palmitic and stearic fatty acids, compared to Lot 197, which registered the highest oleic levels and the lowest linoleic, palmitic and stearic acid levels. This variation should be exploited by groundnut breeders for the purpose of oleic content improvement of Ugandan genotypes by crossing with Lot 197 as the pollen donor with subsequent backcrossing to maintain traits such as rosette resistance in the genetic background of progeny.

\section{ACKNOWLEDGEMENT}

We are thankful to the Alliance for a Green Revolution in Africa (AGRA) 2014 PASS and the Peanut and Mycotoxin Innovation Lab (PMIL) for funding of this study.

\section{REFERENCES}

Barbour, J.A., Howe, P.R., Buckley, J.D., Bryan, J. and Coates, A.M. 2015. Effect of 12 weeks high oleic peanut consumptionon on cardio-metabolic risk factors and body composition. Nutrients 7:7381-7398.

Barkley, N.A., Isleib , G.T., Wang, M.L. and Pittman, R.N. 2013. Genotypic effect of ahFAD2 on fatty acid profiles in six segregating peanut (Arachis hypogaea $\mathrm{L}$ ) populations. BMC Genetics, 14(62) . http:/ /www.biomedcentral.com/1471-2156/14/ 62

Carrillo, C., Cavia, M.M. and Alonso-Torre, S. 2012. Role of Oleic acid in immune system; mechanism of action: A review. Nutricion Hospitalaria 27:978-990.

Chu, Y., Holbrook, C. C. and Ozias-Akins, P. 2009. Two alleles of ahFAD2B conrol the high oleic trait in cultivated peanut. Crop Science 49:2029-2036.

Connor, W.E. 1999. Harbingers of coronary heart disease: dietary saturated fatty acids and cholesterol. Is chocolate benign because of its stearic acid content? American Journal of Clinical Nutrition 70:951-952.

Garcia, M., Garcia, A. and Hernandaz, G.A. 2006. Importance of lipids in the nutritional 
treatment of inflamatory disease. Nutricion Hospitalaria 21:28-41.

Gupta, S.K. 2011. Technological innovations in major world oil crops (1 Ed.). Newyork: Springer. pp. 123-150.

Hassan, F.U. and Ahmed, M. 2012. Oil and fatty acid composition of peanut cultivars grown in Pakistan. Pakistan Journal of Botany 44(2):627-630.

Isleib, T.G., Pattee, E.H., Sanders, T.H., Hendrix, K.W. and Dean, L.O. 2006. Compositional and sensory comparisons between normal- and high- oleic peanuts. Journal of Agricultural and Food Chemistry 54:1759-1763.

Janila, P., Nigam, S.N., Pandey, M.K., Nagesh, P. and Varshney, R.K. 2013. Groundnut improvement: use of genetic and genomic tools. Front Plant Science 4(23). doi: 10.3389/fpls.2013.00023

Janila, P., Pandey, M.K., Shasidhar, Y., Variath, M.T., Sriswathi, M., Khera, P.J., Manohar, S., Nagesh, P., Manish K., Mishra, G., Radhakrishnan, T., Manivannan, N., Dobariya, K.L., Vasanthi, R.P. and Varshney, R.K. 2015. Molecular breeding for introgression of fatty acid desaturase mutant alleles (ahFAD2A and FAD2B) enhances oil quality in high and low oil containing peanut genotypes. Plant Science 242:203-213.

Johnson, S. and Saikia, N. 2009. Fatty acid profiles of edible oils and fats in India, Centre of Science and Environment; pollution Monitoring Laboratory, New Delhi, India. pp. 29, 34, 38.

Kris-Etherton, P.M. 1999. Monounsaturated fatty acids and risk of cardiovascular disease., Circulation 100:1253-1258. doi:10.1161/ 01.CIR.100.11.1253

Mozingo, R.W., Coffelt, T.A. and Wynne, J.C. 1988. Market grade effects on fatty acid composition of five peanut cultivars. Agronomy Journal 80:73-75.

Okello, D.K., Monyo, E., Deom, C.M., Ininda, J. and Oloka, H.K. 2013. Groundnuts production guide for Uganda: Recommended practices for farmers.
Uganda: National Agricultural Research Organization, Government of Uganda. 1pp.

Rizzo, W.B., Watkins, P.A., Phillips, M.W., Cranin, D., Campbell, B. and Avigan, J. 1986. Adrenoleukodystrophy: Oleic acid lowers fibroblast saturated C22-26 fattyacids. Neurology 36:57-61. doi: 3951702.

Rustan, C.A. and Drevon, C.A. 2005. Fatty Acids: Structures and properties. In: Encyclopaedia of life sciences. John Wiley and Sons, Ltd. doi: 10.1038/npg.els. 0003894

Shipley, M.M., Dillwith, J.W., Bowman, A.S., Essenberg, R.C. and Sauer, J.R. 1993. Changes in lipids of the sali- vary glands of the lone star tick, Amblyomma americanum, during feeding. Journal of Parasitology (79):834 - 842.

Singhkam, N., Jogloy, S., Suriharn, B., Kesmala, T., Swatsitang, P., Jaisil, P., Puppala, N. and Patanothai, A. 2012. Types of gene effects governing the inheritance of oleic and linoleic acids in peanut (Arachis hypogaea L.). African Journal of Biotechnology 11(67):1314713152.

Vassiliou, E.K., Gonzalez, A., Garcia, C., Tadros, J.H., Chakraborty, G. and Tonney, J.H. 2009. Oleic acid and peanut oil high in oleic acid reverse the inhibitory effect of insulin production of the inflammatory cytokine TNF-a both invitro and invivo system. Lipids in Health and Disease 8(25): doi:10.1186/1476-511X-8-25PMI

Wang, M.L., Khera, P., Pandey, M.K., Wang, H., Qiao, L., Feng, S., Tonnis, B., Barkeley, N.A., Pinnow, D., Holbrook, C.C., Culbreath, A., Varshney, R.K. and Guo, B. 2015. Genetic mapping of QTLs controlling fatty acids provided insights into the genetic control of fatty acids snthesis pathway in peanut (Arachis hypogea L.). PLOS ONE. doi:10. 1371/ journal.pone.0119454

Whelan, J. 2008. The health implications of changing linoleic acid intakes. Prostaglandins Leukot Essent Fatty Acids 79:165-167. 